\title{
Altered Transition Between Agonist- and Antagonist-Favoring States of $\mu$-Opioid Receptor in Brain Membranes with Modified Microviscosity
}

\author{
Dan F. Lazar and Fedor Medzihradsky \\ Departments of Biological Chemistry and Pharmacology, University of Michigan Medical School, \\ Ann Arbor, Michigan, U.S.A.
}

\begin{abstract}
In unmodified synaptosomal brain membranes the presence of $\mathrm{NaCl}$ inhibited the binding to $\mu$ receptors of the tritiated opioid agonists etorphine, Tyr-D-Ala-Gly(Me)Phe-Gly-ol, and sufentanil by 53,43 , and $37 \%$, respectively, and increased that of the antagonist $\left[{ }^{3} \mathrm{H}\right]$ naltrexone by $54 \%$. On the other hand, in membranes whose microviscosity was increased by incorporation of cholesteryl hemisuccinate (CHS) the effects of sodium on opioid agonist and antagonist binding were abolished and strongly reduced, respectively. Furthermore, in the modified membranes the ability of sodium to protect the opioid receptor from inactivation by the sulfhydryl-reactive agent $N$-ethylmaleimide (NEM) was diminished. In CHS-treated membranes whose elevated microviscosity was reduced by the incorporation of oleic acid, the effectiveness of sodium in modulating opioid binding and attenuating receptor inactivation by NEM was restored. The results implicate membrane microviscosity in the mechanism by which sodium modulates the conversion between agonist- and antagonist-favoring states of $\mu$ opioid receptor. Key Words: Rat brain cortex-Fluorescence polarization-Membrane fluidity-Opioid agonists and antagonists-CholesterolFatty acids.

J. Neurochem. 61, 1135-1140 (1993).
\end{abstract}

The function of intrinsic membrane proteins has been shown to depend on the lipid bilayer within which they reside. This modulation either occurs as a result of specific lipid-protein interactions (Tefft et al., 1986) or involves changes in the bulk physical properties of the membrane such as microviscosity (Swann, 1984). Specifically, altered membrane lipid composition (Fong and MacNamee, 1987) or membrane microviscosity (Zhang and Yang, 1989) has affected the conformation of membrane proteins. There is ample evidence for the sensitivity of opioid receptor function to lipids: Reconstitution experiments with partially purified receptor have demonstrated a requirement for specific lipids to support high-affinity opioid binding (Hasegawa et al., 1987), and ligand interaction with opioid receptors in brain was strongly influenced by the fluidity of the membrane environment (Remmers et al., 1990; Lazar and Medzihradsky, 1992).

Based on (a) the ability of sodium to enhance opioid antagonist binding while reducing that of agonist (Pert et al., 1973), (b) the distinct inhibition of opioid agonists and antagonists binding by proteinmodifying reagents (Pasternak et al., 1975), and (c) protection by sodium of receptor inactivation by the sulfhydryl-reactive agent $N$-ethylmaleimide (NEM) (Simon and Groth, 1975), a two-state model for opioid receptor was forwarded in which sodium induces the conversion of the receptor from an "agonist" to an "antagonist" conformation (Pasternak and Snyder, 1975; Simon and Groth, 1975; Simon and Hiller, 1981). Considering the evidence for a role of membrane fluidity in the conformational transition of proteins and in the modulation of opioid receptor binding, we have in this study examined the sodium-induced conversion between the agonist- and antagonist-favoring states of opioid receptor in brain membranes with altered microviscosity.

\section{MATERIALS AND METHODS}

\section{Materials}

$\left[{ }^{3} \mathrm{H}\right]$ Etorphine (specific activity, $40 \mathrm{Ci} / \mathrm{mmol}$ ) and $\left[{ }^{3} \mathrm{H}\right]$ Tyr-D-Ala-Gly-(Me)Phe-Gly-ol ([ $\left.{ }^{3} \mathrm{H}\right] \mathrm{DAMGO}$; specific activity, $60 \mathrm{Ci} / \mathrm{mmol}$ ) were purchased from Amersham Co., whereas $\left[{ }^{3} \mathrm{H}\right]$ sufentanil (specific activity, $54 \mathrm{Ci} / \mathrm{mmol}$ ) and $\left[{ }^{3} \mathrm{H}\right]$ naltrexone (specific activity, $22 \mathrm{Ci} / \mathrm{mmol}$ ) were obtained from Janssen Life Sciences Products and the Na-

Received November 12, 1992; revised manuscript received January 22, 1993; accepted February 4, 1993.

Address correspondence and reprint requests to Dr. F. Medzihradsky at Department of Biological Chemistry, University of Michigan Medical School, Ann Arbor, MI 48109-0606, U.S.A.

Abbreviations used: CHS, cholesteryl hemisuccinate; DAMGO, Tyr-D-Ala-Gly-(Me)Phe-Gly-ol; DPH, diphenylhexatriene; GTP$\gamma-\mathrm{S}$, guanosine 5 - $(\gamma$-thio)triphosphate; NEM, $N$-ethylmaleimide; $\mathrm{OA}$, oleic acid; TMA-DPH, trimethylammonium-diphenylhexatriene. 
tional Institute on Drug Abuse, respectively. All unlabeled opioids were supplied by the Narcotic Drug and Opiate Peptide Basic Research Center at the University of Michigan. Cholesteryl hemisuccinate (CHS), cis-9-octadecenoic acid [oleic acid (OA)], NEM, and dithiothreitol were obtained from Sigma Chemical Co., whereas diphenylhexatriene (DPH) and trimethylammonium-DPH (TMA-DPH) were obtained from Molecular Probes, Inc.

\section{Membrane preparation}

Synaptosomal membranes were obtained from brain cortices of male Sprague-Dawley rats as described previously (Cahill and Medzihradsky, 1976; Lazar and Medzihradsky, 1992). The isolated membranes were suspended in $50 \mathrm{~m} M$ Tris- $\mathrm{HCl}(\mathrm{pH} 7.4$ ) at a concentration of $3 \mathrm{mg}$ of protein $/ \mathrm{ml}$ and stored at $-80^{\circ} \mathrm{C}$ until use. After solubilization with $1 \mathrm{M}$ $\mathrm{NaOH}$ for $30 \mathrm{~min}$ at $25^{\circ} \mathrm{C}$, membrane protein was quantified according to the procedure of Lowry et al. (1951), using bovine serum albumin as the standard.

\section{Membrane modification with CHS and OA}

CHS $(0.25-2 \mu \mathrm{mol} / \mathrm{mg}$ of membrane protein) or $\mathrm{OA}$ $(0.155-0.7 \mu \mathrm{mol} / \mathrm{mg}$ of protein) was added as a solution in ethanol to membranes $(1 \mathrm{mg}$ of protein $/ \mathrm{ml})$ suspended in $50 \mathrm{~m} M$ Tris- $\mathrm{HCl}$ ( $\mathrm{pH}$ 7.4) with vigorous mixing. Control membranes were incubated with a corresponding volume of ethanol. After incubation for $30 \mathrm{~min}$ at $25^{\circ} \mathrm{C}$, the mixture was centrifuged for $15 \mathrm{~min}$ at $22,500 \mathrm{~g}$, and the resultant pellet was resuspended in the Tris buffer using a Dounce homogenizer.

\section{Measurement of membrane microviscosity}

The fluorescent probe DPH or its cationic derivative TMA-DPH was incubated at $25^{\circ} \mathrm{C}$ with membranes $(50 \mu \mathrm{g}$ of protein) at a ratio of membrane phospholipid/probe of 200:1, and fluorescence polarization was measured at excitation and emission wavelengths of 340 and $450 \mathrm{~nm}$, respectively, as described (Lazar and Medzihradsky, 1992). The results were expressed as anisotropy values $(r)$, where $r=\left(I_{0}\right.$ $\left.-I_{90}\right) /\left(I_{0}-2 I_{90}\right)$, and $I_{0}$ and $I_{90}$ represent the intensities of light with polarizers in a parallel or perpendicular orientation, respectively.

\section{Ligand binding}

Equilibrium binding of $\left[{ }^{3} \mathrm{H}\right]$ etorphine, $\left[{ }^{3} \mathrm{H}\right]$ naltrexone, $\left[{ }^{3} \mathrm{H}\right] \mathrm{DAMGO}$, and $\left[{ }^{3} \mathrm{H}\right]$ sufentanil was determined in principle as previously described (Fischel and Medzihradsky, 1981). In brief, assay tubes containing 150-200 $\mu \mathrm{g}$ of membrane protein were exposed to $5 \mu M$ guanosine $5^{\prime}-(\gamma$ thio)triphosphate (GTP- $\gamma-S)$ in the absence or presence of $150 \mathrm{mM} \mathrm{NaCl}$ for $15 \mathrm{~min}$ at $25^{\circ} \mathrm{C}$. Subsequently, the samples were incubated with the opioids at $25^{\circ} \mathrm{C}$ to attain equilibrium in binding ( $30-80 \mathrm{~min}$ ). Specific binding of the radiolabeled ligand was determined in the absence and presence of an excess $(1 \mu M)$ of the appropriate unlabeled ligand. Binding of the radioligands to $\delta$ receptors was blocked by $50 \mathrm{n} M$ oxymorphindole (Remmers and Medzihradsky, 1991a). Reflecting the low density of $k$ receptors in the membrane preparation used (Remmers and Medzihradsky, 199(a), the $\kappa$-selective opioid U69,593 had no effect on the binding of the tritiated ligands. Interference by $\kappa$-receptor subtypes to which U69,593 does not bind was unlikely, because of the potent effects of low concentrations of highly $\mu$-selective opioids, described below.

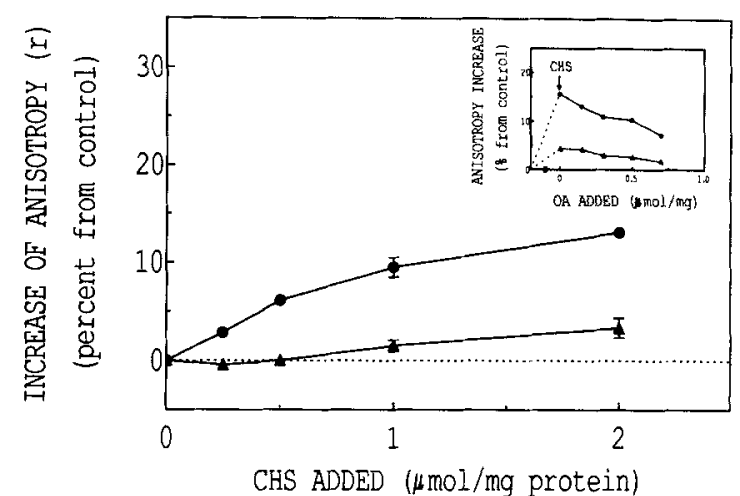

FIG. 1. Microviscosity of lipid-modified membranes. Synaptosomal membranes from rat brain cortex were incubated with increasing concentrations of CHS or with $2 \mu \mathrm{mol}$ of $\mathrm{CHS} / \mathrm{mg}$ of membrane protein followed by increasing concentrations of $O A$ (inset). After the incorporation of DPH (-) or TMA-DPH (A), fluorescence anisotropy $(r)$ was determined as described in Materials and Methods. Data are mean \pm SEM (bars) values of three experiments, each carried out in duplicate.

\section{NEM inactivation of opioid binding}

Membranes, suspended in $50 \mu M$ Tris $\mathrm{HCl}(\mathrm{pH} 7.4)$ at a concentration of $1 \mathrm{mg}$ of protein $/ \mathrm{ml}$, were preincubated with $5 \mu M$ GTP- $\gamma-S$ in the absence or presence of $150 \mathrm{mM}$ $\mathrm{NaCl}$ for $15 \mathrm{~min}$ at $25^{\circ} \mathrm{C}$. Subsequently, the membrane suspension was incubated with $3 \mathrm{~m} M$ NEM for various intervals, after which receptor inactivation was terminated by addition of $10 \mathrm{~m} M$ dithiothreitol. The membranes were then centrifuged for $15 \mathrm{~min}$ at $22,500 \mathrm{~g}$ and washed with 10 -fold the original volume of ice-cold buffer. The washed pellet was resuspended in $50 \mathrm{mM}$ Tris- $\mathrm{HCl}(\mathrm{pH} \mathrm{7.4)}$ at a protein concentration of $1 \mathrm{mg}$ of protein $/ \mathrm{ml}$. Residual $\mu$ opioid receptor binding was assayed with $0.5 \mathrm{n} M\left[{ }^{3} \mathrm{H}\right]-$ naltrexone at $25^{\circ} \mathrm{C}$ in the presence of $150 \mathrm{mM} \mathrm{NaCl}$ and 50 $\mathrm{n} M$ oxymorphindole.

\section{RESULTS}

As shown by the fluorescence anisotropy of the membrane probes DPH and TMA-DPH, the addition of CHS increased the microviscosity of both the core and surface regions of brain membrane (Fig. 1). Whereas the increase in DPH anisotropy over that in control membranes was statistically significant (unpaired Student's $t$ test by $p<0.05$ ) at all concentrations of CHS added $(0.25-2 \mu \mathrm{mol} / \mathrm{mg}$ of membrane protein), the rise in TMA-DPH anisotropy became significant at a concentration of $1 \mu \mathrm{mol}$ of $\mathrm{CHS} / \mathrm{mg}$ of membrane protein. The microviscosity of control and modified membranes was unaffected by the absence or presence of $150 \mathrm{mM} \mathrm{NaCl}$ (data not shown). Increasing concentrations of $\mathrm{OA}$ added to membranes previously rigidified by CHS progressively restored the microviscosity toward the level in unmodified membranes (Fig. 1, inset). In addition, increasing the temperature of control and CHS-treated membranes from 25 to $37^{\circ} \mathrm{C}$ substantially decreased the microvis- 


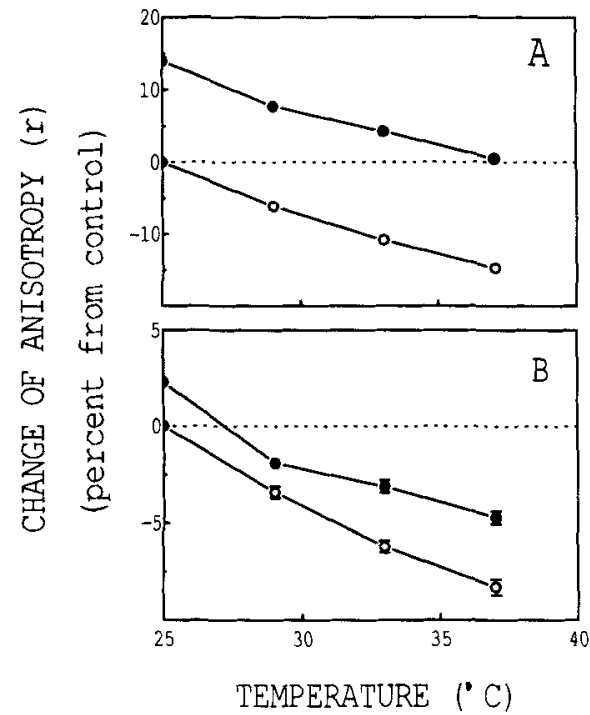

FIG. 2. Effect of temperature on membrane microviscosity. Untreated synaptosomal membranes $(\mathrm{O})$ and membranes modified by addition of $2 \mu \mathrm{mol}$ of $\mathrm{CHS} / \mathrm{mg}$ of membrane protein (๑) were incubated with fluorescent probes as described in Materials and Methods. After the incorporation of DPH (A) or TMA-DPH (B), fluorescence anisotropy was determined at temperatures ranging from 25 to $37^{\circ} \mathrm{C}$. At $25^{\circ} \mathrm{C}$, the DPH and TMA-DPH anisotropy values were 0.249 and 0.287 , respectively. Data are mean \pm SEM (bars) values of three experiments, each carried out in duplicate.

cosity of the core and surface regions of the membrane (Fig. 2).

To avoid differential effects of membrane modification on free and $G$ protein-coupled opioid receptors and to allow a direct comparison of agonist and antagonist binding, GTP- $\gamma-\mathrm{S}$ was used to uncouple the receptor (Remmers and Medzihradsky, 1991b); the validity of this approach was evaluated in previous studies on lipid modulation of opioid receptor binding (Remmers et al., 1990; Lazar and Medzihradsky, 1992). Furthermore, all binding assays were carried out in the presence of the potent $\delta$-selective opioid oxymorphindole to block radioligand interaction with the $\delta$ receptor. Under such conditions, in control membranes $150 \mathrm{~m} M \mathrm{NaCl}$ reduced the specific binding of $0.5 \mathrm{n} M\left[{ }^{3} \mathrm{H}\right]$ etorphine by $53 \%$ and increased that of $0.5 \mathrm{n} M\left[{ }^{3} \mathrm{H}\right]$ naltrexone by $54 \%$ (Fig. 3 ). The concentration of $150 \mathrm{mM} \mathrm{NaCl}$ was selected considering its widespread use to discriminate between the binding of opioid agonists and antagonists in brain membranes. However, in the present work, $\mathrm{NaCl}$ modulated ligand binding in both control and lipidmodified membranes with an $\mathrm{EC}_{50}$ of $6 \mathrm{mM}$, exhibiting a maximal effect at $25 \mathrm{mM}$ (data not shown).

In membranes treated with CHS the resolution by sodium of agonist and antagonist binding was strongly diminished: At the highest concentration of CHS examined ( $2 \mu \mathrm{mol} / \mathrm{mg}$ of membrane protein), modulation of $\left[{ }^{3} \mathrm{H}\right]$ etorphine binding was abolished, whereas the enhancement of $\left[{ }^{3} \mathrm{H}\right]$ naltrexone binding was limited to $10 \%$. In contrast, in the absence of sodium, CHS produced a pattern described earlier (Lazar and Medzihradsky, 1992): Both agonist and antagonist binding was elevated (Fig. 3, inset). The decision to use primarily $\left[{ }^{3} \mathrm{H}\right]$ etorphine as a $\mu$ ligand was based on two considerations: (a) Compared with the $\mu$-selective opioid DAMGO, the binding of etorphine exhibited stronger responses to sodium (Clark et al., 1988), and (b) binding of $\left[{ }^{3} \mathrm{H}\right]$ etorphine was originally used to demonstrate the protection by sodium of receptor inactivation by NEM (Simon and Groth, 1975). However, membrane modification by CHS also suppressed the sodium effect on receptor binding of the $\mu$ agonists $\left[{ }^{3} \mathrm{H}\right]$ DAMGO (by $42.8 \%$ ) and $\left[{ }^{3} \mathrm{H}\right]$ sufentanil (by $37.4 \%$ ). Whereas in control membranes sodium inhibited the binding of $2 \mathrm{n} M\left[{ }^{3} \mathrm{H}\right] \mathrm{DAMGO}$ by $77.0 \%$ and of $0.5 \mathrm{nM}\left[{ }^{3} \mathrm{H}\right]$ sufentanil by $66.3 \%$, in membranes modified by CHS ( $2 \mu \mathrm{mol} / \mathrm{mg}$ of membrane protein) the inhibition by sodium was reduced to 44.0 and $41.5 \%$, respectively.

Addition of OA to membranes previously modified with CHS completely restored the enhancement by sodium of antagonist binding (Fig. 4). At a concentration of $0.5 \mu \mathrm{mol}$ of $\mathrm{OA} / \mathrm{mg}$ of membrane protein, the increase was $>50 \%$, after having been reduced to $10 \%$ in the corresponding CHS-treated membranes. As observed previously (Remmers et al., 1990), increasing concentrations of $\mathrm{OA}$, in the absence or presence of sodium, inhibited the binding of both opioid agonists and antagonists (Fig. 4, inset). In addition to the fluidizing effect (Fig. 2), elevation of temperature from 25 to $37^{\circ} \mathrm{C}$ completely restored sodium modulation of antagonist binding in membranes previously rigidi-

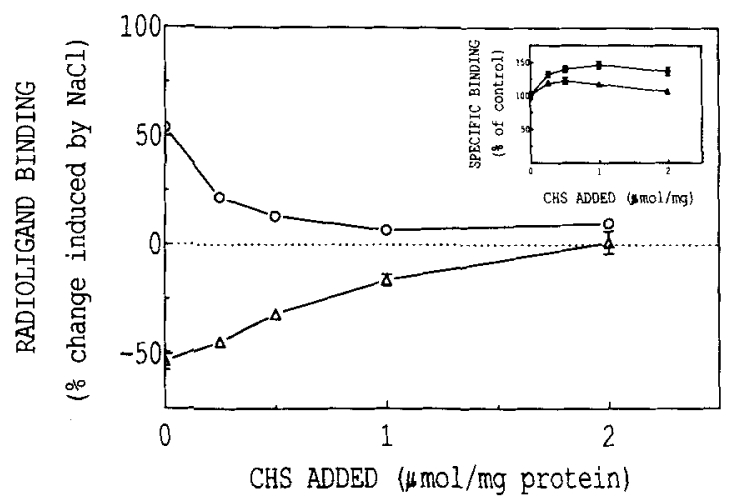

FIG. 3. Sodium modulation of opioid binding in control and CHSmodified membranes. After treatment of membranes with increasing concentrations of CHS, the specific binding of $0.5 \mathrm{nM}$ $\left[{ }^{3} \mathrm{H}\right]$ etorphine (triangles) or $0.5 \mathrm{nM}\left[{ }^{3} \mathrm{H}\right]$ naltrexone (circles) was determined in the absence (solid symbols) and presence (open symbols) of $150 \mathrm{~m}: \mathrm{M} \mathrm{NaCl}$. Ligand binding was carried out in the presence of $50 \mathrm{n} M$ oxymorphindole and $5 \mu M$ GTP- $\gamma-\mathrm{S}$. Plotted are the sodium effects on ligand binding relative to binding (fmol/ $\mathrm{mg}$ of membrane protein) performed in the absence of sodium (inset): $\left[{ }^{3} \mathrm{H}\right]$ etorphine, $186.9 \pm 8.9 ;\left[{ }^{3} \mathrm{H}\right]$ naltrexone, $64.6 \pm 3.5$. Data are mean \pm SEM (bars) values of three experiments, each carried out in duplicate. 


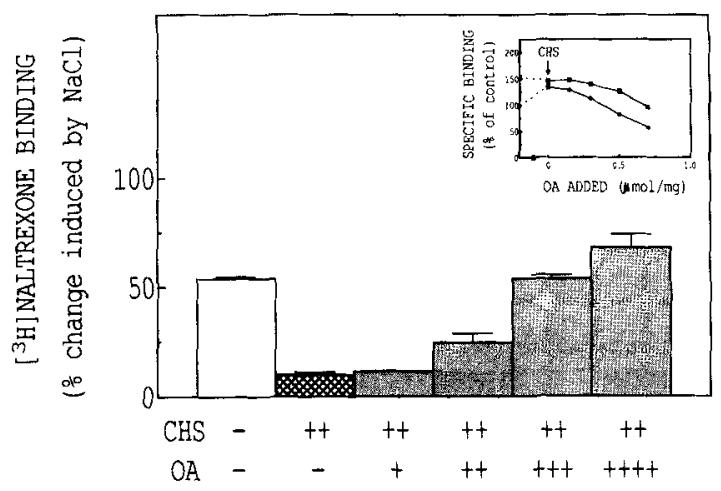

FIG. 4. Reversal by OA of the sodium effect on opioid binding in CHS-modified membranes. Membranes treated with $2 \mu \mathrm{mol}$ of $\mathrm{CHS} / \mathrm{mg}$ of protein $(++)$ were subsequently modified by addition of increasing concentrations (per milligram of membrane protein) of OA: $0.15(+), 0.3(t+), 0.5(t+t)$, and $0.7(t+++) \mu \mathrm{mol}$. The specific binding of $0.5 \mathrm{nM}\left[{ }^{3} \mathrm{H}\right]$ naltrexone in control and $\mathrm{CHS}(2$ $\mu \mathrm{mol} / \mathrm{mg}$ of protein)- and OA-modified membranes was then determined in the absence (O) and presence (a) of $150 \mathrm{mM} \mathrm{NaCl}$ and in the presence of $50 \mathrm{nM}$ oxymorphindole and $5 \mu M$ GTP- $\gamma-S$ (inset). Plotted is the enhancement of ligand binding by sodium relative to binding determined in its absence $(68.7 \pm 3.9 \mathrm{fmol} / \mathrm{mg}$ of membrane protein). Data are mean \pm SEM (bars) values of three experiments, each carried out in duplicate.

fied by CHS incorporation (Fig. 5). In contrast, sodium enhancement of $\left[{ }^{3} \mathrm{H}\right]$ naltrexone binding in untreated membranes was unaffected by the increase in temperature.

Incubation of untreated membranes with NEM caused a progressive inhibition of $\left[{ }^{3} \mathrm{H}\right]$ naltrexone

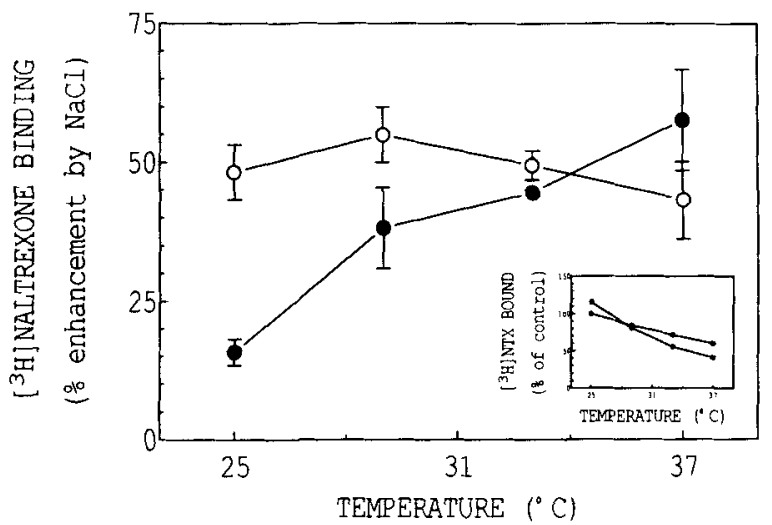

FIG. 5. Reversal by increased temperature of the sodium effect on opioid binding in CHS-modified membranes. Specific binding of $0.5 \mathrm{nM}\left[{ }^{3} \mathrm{H}\right]$ naltrexone was determined at temperatures ranging from 25 to $37^{\circ} \mathrm{C}$ in the absence (inset) and presence of 150 $\mathrm{mM} \mathrm{NaCl}$ in untreated synaptosomal membranes $(O)$ and membranes modified by addition of $2 \mu \mathrm{mol}$ of $\mathrm{CHS} / \mathrm{mg}$ of membrane protein $(\bullet)$. The binding assays were performed in the presence of $50 \mathrm{nM}$ oxymorphindole and $5 \mu M$ GTP- $\gamma$-S. Plotted is the enhancement of ligand binding by sodium relative to binding determined in its absence $(67.5 \pm 4.4 \mathrm{fmol} / \mathrm{mg}$ of membrane protein). Data are mean \pm SEM (bars) values of three experiments, each carried out in duplicate.

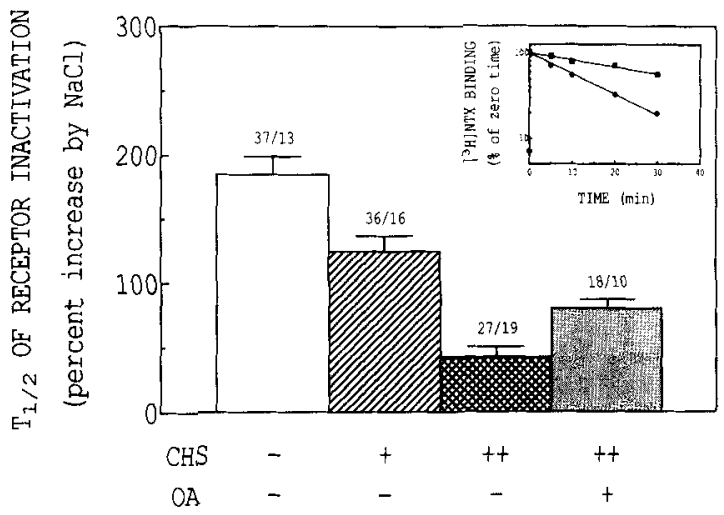

FIG. 6. Inactivation by NEM of opioid binding in control and modified membranes. After pretreatment with $0(-), 1(+)$, or $2(++)$ $\mu \mathrm{mol}$ of CHS and with $0(-)$ or $0.2 \mu \mathrm{mol}$ of $\mathrm{OA} / \mathrm{mg}$ of membrane protein $(+)$, brain membranes were incubated with $3 \mathrm{mM}$ NEM for various intervals in the absence (ब) or presence (D) of $150 \mathrm{mM}$ $\mathrm{NaCl}$. Subsequently, binding of $0.5 \mathrm{nM}\left[{ }^{3} \mathrm{H}\right]$ naltrexone in the presence of $150 \mathrm{mM} \mathrm{NaCl}, 50 \mathrm{nM}$ oxymorphindole, and $5 \mu M$ GTP- $\gamma$-S was determined. Plotted is the effect of $\mathrm{Na}^{+}$on the $t_{1 / 2}$ of receptor inactivation determined by ligand binding; the numbers above the columns represent the $t_{1 / 2}$ values in the presence/absence of sodium. Data are mean \pm SEM (bars) values of three experiments, each carried out in duplicate. Inset: Time-dependent inactivation of receptor by NEM in untreated membranes, observed in a representative experiment. In the control membranes, subjected to a "sham" procedure of NEM inactivation, the extent of $\left[{ }^{3} \mathrm{H}\right]$ naltrexone binding in the presence of sodium was $72.9 \mathrm{fmol} / \mathrm{mg}$ of membrane protein.

binding to the $\mu$ receptor, whereby receptor inactivation followed pseudo-first-order kinetics (Fig. 6, inset). In these membranes, sodium potently attenuated the rate of receptor inactivation, increasing the $t_{1 / 2}$ by $185 \%$ (Fig. 6). In contrast, in membranes rigidified by CHS the enhancement of the $t_{1 / 2}$ by sodium was limited to $42 \%$. Subsequent addition of OA to the CHSmodified membranes restored sodium protection to $80 \%$ of that observed in untreated, control membranes (Fig. 6).

\section{DISCUSSION}

Disruption of membrane order can significantly affect the conformation of integral membrane proteins. For example, fluidization of rat brain membranes by ethanol, fatty acid, or elevation of temperature stabilized the conformation of $\mathrm{Na}^{+}, \mathrm{K}^{+}$-ATPase that exhibits high affinity for ATP over that tightly binding $\mathrm{K}^{+}$(Swann, 1984), whereas an increase in membrane lipid order due to either cholesterol incorporation or a decrease in temperature favored the formation of the meta I over the meta II conformation of bovine rhodopsin (Mitchell et al., 1990).

Based on the strong modulation of ligand binding to opioid receptors in fluidized and rigidified membranes (Remmers et al., 1990; Lazar and Medzihradsky, 1992), it was postulated that the sodiuminduced transition between the agonist- and antago- 
nist-favoring states of opioid receptor will be affected by modified membrane microviscosity. In membranes rigidified by $\mathrm{CHS}$, the more effective packing of phospholipids in the bilayer reduces the "free volume" available for occupation by an integral membrane protein. Therefore, conformational changes of receptor requiring transient or stable expansion of the protein's structure may be inhibited by the increased order of the membrane bilayer (Yeagle, 1991). In such a manner, rigidification of the synaptosomal membranes by CHS could resist the sodium-induced shift of the opioid receptor from the "agonist" to the "antagonist" conformation proposed earlier (Pasternak and Snyder, 1975; Simon and Groth, 1975). If this were the case, subsequent fluidization of the membrane would be expected to restore the efficacy of sodium displayed in the unmodified membranes. Consistent with this hypothesis, raising the temperature from 10 to $37^{\circ} \mathrm{C}$, a process shown to decrease membrane microviscosity (Fig. 2), progressively increased the effect of sodium on $\left[{ }^{3} \mathrm{H}\right]$ etorphine binding to opioid receptors in rat brain membranes (Hitzemann et al., 1985). The strong and differential sensitivity of opioid agonist and antagonist binding to temperature has been reported earlier (Creese et al., 1975).

Indeed, the results of the present study support the considerations outlined above. $\mathrm{NaCl}$ by itself had no effect on membrane microviscosity, but incorporation of CHS rigidified both "core" and "surface" regions of the membrane. In these membranes the potent modulation by sodium of the binding to $\mu$ receptor of both alkaloid and peptide opioid agonists as well as alkaloid antagonists, seen in control membranes, was abolished or strongly reduced. In addition, CHS incorporation decreased the ability of sodium to protect the receptor against inactivation by NEM. These results are consistent with a restriction of the sodium-induced transition of receptor states in the rigidified membranes as compared with the conversion between these "agonist" and "antagonist" states occurring in control membranes. The involvement of membrane microviscosity in the latter process was strongly supported by restoration of the sodium effect on ligand binding and on receptor protection following fluidization of the CHS-treated membranes with OA. The potent effects of this cisunsaturated fatty acid on membrane microviscosity have previously been described (Remmers et al., 1990; Lazar and Medzihradsky, 1992).

A role of modulation through altered membrane microviscosity was also indicated by the complete restoration of sodium enhancement of $\left[{ }^{3} \mathrm{H}\right]$ naltrexone binding in CHS-treated membranes that were subsequently fluidized by temperature elevation. The inability of increasing temperature to enhance sodium modulation of antagonist binding in control membranes could indicate a threshold level of membrane microviscosity below which transition between the two states of $\mu$-opioid receptor is completely supported.
Notwithstanding the implication of membrane microviscosity, the results of this study do not rule out a direct interaction of the added lipids with opioid receptor, as described for CHS and membrane proteins such as glycophorin (Yeagle, 1991) or the nicotinic acetylcholine receptor (Fong and McNamee, 1987). It should also be noted that, as described for temperature (Treistman et al., 1987), the effect of membrane modifications on the biophysical state of a particular lipid domain may be different from that observed in bulk membranes. Clearly, the molecular phenomena underlying the observed potent effects of sodium in modulating opioid binding will require additional research, particularly focusing on the site of ion action and on the role of sulfhydryl groups postulated at the binding domain of the $\mu$ receptor (Ofri and Simon, 1992) and shown to be part of the recently disclosed sequence of a $\delta$-opioid receptor (Evans et al., 1992; Kieffer et al., 1992). On the other hand, the data of this study strongly support a role of the membrane microenvironment, involving its microviscosity, in the mechanism by which sodium modulates the transition between the agonist- and antagonist-favoring states of opioid receptor. The physiological significance of the findings is supported by the manifold conditions, such as development, aging, diet, and disease, that modulate the lipid composition and fluidity of cell membranes (Lazar and Medzihradsky, 1992). It is of interest to note that in the present study low concentrations of $\mathrm{NaCl}$, approximating intracellular levels, were able to modulate the conversion between the two states of $\mu$ receptor. An intracellular site of sodium action in regulating opioid receptor binding has previously been suggested (Puttfarcken et al., 1986).

Acknowledgment: The authors thank Ms. Rebecca McLaughlin for expert secretarial assistance. This work was supported by U.S. Public Health Service grant DA04087.

\section{REFERENCES}

Cahill A. L. and Medzihradsky F. (1976) Interaction of central nervous system drugs with synaptosomal transport processes. Biochem. Pharmacol. 25, 2257-2264.

Clark M. J., Carter B. D., and Medzihradsky F. (1988) Selectivity of ligand binding to opioid receptors in brain membranes from the rat, monkey and guinea pig. Eur. J. Pharmacol. 148, 343351.

Creese I., Pasternak G., Pert C. B., and Snyder S. H. (1975) Discrimination by temperature of opiate agonist and antagonist receptor binding. Life Sci. 16, 1837-1842.

Evans C. J., Keith D. E. Jr., Morrison H., Magendzo K., and Edwards R. H. (1992) Cloning of a $\delta$ opioid receptor by functional expression. Science 258, 1952-1955.

Fischel S. V. and Medzihradsky F. (1981) Scatchard analysis of opiate receptor binding. Mol. Pharmacol. 20, 269-279.

Fong T. M. and McNamee M. G. (1987) Stabilization of acetylcholine receptor secondary structure by cholesterol and negatively charged phospholipids in membranes. Biochemistry 26, 3871 3880 .

Hasegawa J.-I., Loh H. H., and Lee N. M. (1987) Lipid requirement for $\mu$ opioid receptor binding. $J$. Neurochem. 49, 1007-1012. 
Hitzemann R., Murphy M., and Curell J. (1985) Opiate receptor thermodynamics: agonist and antagonist binding. Eur. $J$. Pharmacol. 108, 171-177.

Kieffer B. L., Befort K., Gaveriaux-Ruff C., and Hirth C. G. (1992) The $\delta$-opioid receptor: isolation of a cDNA by expression cloning and pharmacological characterization. Proc. Natl. Acad. Sci. USA 89, 12048-12052.

Lazar D. F. and Medzihradsky F. (1992) Altered microviscosity at brain membrane surface induces distinct and reversible inhibition of opioid receptor binding. J. Neurochem. 59, 1233-1240.

Lowry O. H., Rosebrough N. J., Farr A. L., and Randall R. J. (1951) Protein measurement with the Folin phenol reagent. $J$. Biol. Chem. 193, 265-275.

Mitchell D. C., Straume M., Miller J. L., and Litman B. J. (1990) Modulation of metarhodopsin formation by cholesterol-induced ordering of bilayer lipids. Biochemistry 29, 9143-9149.

Ofri D. and Simon E. J. (1992) Sulfhydryl groups on opioid receptors revisited. Evidence for two sulfhydryl groups at or near the active site of the $\mu$ opioid receptor. Receptor 2, 109-119.

Pasternak G. and Snyder S. H. (1975) Identification of novel high affinity opiate receptor binding in rat brain. Nature 253, 563565.

Pasternak G., Wilson A., and Snyder S. H. (1975) Differential effects of protein-modifying reagents on receptor binding of opiate agonists and antagonists. Mol. Pharmacol. 11, 340-351.

Pert C. B., Pasternak G., and Snyder S. H. (1973) Opiate agonists and antagonists discriminated by receptor binding in brain. Science 182, 1359-1361.

Puttfarcken P., Werling L. L., Brown S. R., Cote T. E., and Cox B. M. (1986) Sodium regulation of agonist binding at opioid receptors. I. Effects of sodium replacement on binding at $\kappa$ and $\delta$-type receptors in $7315 \mathrm{c}$ and NG108-15 cells and cell membranes. Mol. Pharmacol. 30, 81-89.
Remmers A. E. and Medzihradsky F. (1991a) Resolution of biphasic binding of the opioid antagonist naltrexone in brain membranes. J. Neurochem. 57, 1265-1269.

Remmers A. E. and Medzihradsky F. (1991b) Reconstitution of high-affinity opioid agonist binding in brain membranes. Proc. Natl. Acad. Sci. USA 88, 2171-2175.

Remmers A. E., Nordby G. L., and Medzihradsky F. (1990) Modulation of opioid receptor binding by cis and trans fatty acids. $J$. Neurochem. 55, 1993-2000.

Simon E. J. and Groth J. (1975) Kinetics of opiate receptor inactivation by sulfhydryl reagents: evidence for conformational change in presence of sodium ions. Proc. Natl. Acad. Sci. USA 72, 2404-2407.

Simon E. J. and Hiller J. M. (1981) Opioid peptides and opiate receptors, in Basic Neurochemistry (Siegel G. J., Albers R. W., Agranoff B. W., and Katzman R., eds), pp. 255-268. Little, Brown, Boston.

Swann A. C. (1984) Free fatty acids and $\left(\mathrm{Na}^{+}, \mathrm{K}^{+}\right)$-ATPase: effects on cation regulation, enzyme conformation, and interactions with ethanol. Arch. Biochem. Biophys. 233, 354-361.

Tefft R. E., Carruthers A., and Melchior D. L. (1986) Reconstituted human erythrocyte sugar transporter activity is determined by bilayer lipid head group. Biochemistry 25, 3709-3718.

Treistman S. N., Moynihan M. M., and Wolf D. E. (1987) Influence of alcohol, temperature, and region on the mobility of lipids in neuronal membrane. Biochim. Biophys. Acta 898, $109-120$.

Yeagle P. L. (1991) Modulation of membrane function by cholesterol. Biochimie 73, 1303-1310.

Zhang X. F. and Yang F. Y. (1989) Further study on the role of $\mathrm{Mg}^{2+}$ in lipid-protein interaction in reconstituted porcine heart mitochondrial $\mathrm{H}^{+}$-ATPase. Biochim. Biophys. Acta 976 , $53-62$. 